\title{
Development of Human Mechanic Interface Auotonics S070 Trainer for Electric Motor Installation Learning
}

\author{
Supari Muslim, Setyo Budi Karno, Widi Aribowo, Fandi Achmad \\ Electrical Engineering Department \\ Universitas Negeri Surabaya \\ Surabaya, Indonesia \\ supari@unesa.ac.id
}

\begin{abstract}
This study aims to determine the performance and feasibility of Media Learning Trainer Human Mechanic Interface on Electric Motor Installation subjects. This research is done through the following stages: (1) analysis; (2) design; (3) implementation; (4) validation; (5) testing; and (6) experiments in classroom learning. The methods used in data collection include: (1) testing and observing performance of Trainer Human Mechanic Interface; (2) through questionnaire to know the student response; and (3) the feasibility test and construct test for Trainer Human Mechanic Interface is done by two media instructional experts. Research finds: (1) test of media content, by expert of learning media, obtained "very decent category" with percentage equal to $89,58 \%$,: (2) test of media content, by expert of learning media, obtained "very decent category" with percentage equal to $89,58 \%$; and (3) media trials in learning of 30 students in SMK Special Navy 1 Surabaya, obtained "very decent category" with percentage equal to $83.04 \%$.
\end{abstract}

keywords-component, human mechanics interface, electric motor installation

\section{INTRODUCTION}

Education is a human conscious effort to guide people to develop personality and abilities in accordance with the values prevailing in society and culture. According to Law no. 20 Year 2003 Article 1 paragraph 1 of the National Education System that education is a conscious and planned effort to create an atmosphere of learning and learning process that encourages students to actively develop their potential to have religious power, self-control, personality, intelligence, noble character, and skills needed himself, society, nation, and country.

Student learning achievement is influenced by various factors. According reference [1] the factors that affect learning achievements of many types. One of the factors that has an influence in achieving learning outcomes is the learning media used during teaching and learning process [1]. According to reference [2] in his research explains that "the role of learning media has a significant influence on the achievement of learners".

In Law no. 14 Year 2005 article 1 clause 1 on Teachers and Lecturers explains that Teachers are professional educators with the main task of educating, teaching, guiding, directing, training, assessing and evaluating learners in early childhood education formal education, basic education and education medium.

The professionalism of a teacher as an educator is not the ability to develop science, but on the ability to carry out an interesting and meaningful learning process for students. One of the teacher's efforts to support the learning process is interesting, that is by doing learning innovation. Innovation by the teacher should try to make the learning materials delivered can be easily absorbed and understood by the learners. The development of information and technology is a learning innovation, especially on learning media. Utilization of information and technology can be attempted to create a learning media that can make learners can actively perform the learning process, where the role of learners not only as a recipient, but also actively get a meaningful learning experience.

According to reference [3], that media comes from the word medium which means something that is designed, in order to reach many users, including students in learning. Meanwhile, according to reference [4] that the educational media is a communication channel that carries messages with instructional purpose. While reference [5] view that the media is a means to transmit messages in the perspective of learning. By leveraging the media, the learning process becomes more interesting, and also more effective [3]. Reference [4] classified educational media into 5 classifications: (1) print media; (2) non-printing media; (3) electronic media; (4) audio media, \& visual media; and (5) hardware and soffware media.

There are several results of research on learning media, especially about the use of car learning as a medium of learning. Reference [6] in his research entitled "mobile learning in higher education" found that: (1) when in the classroom, students most often use their tools to access information; (2) teachers assume that students only use their devices to socialize by messaging each other, due to potential ignorance possessed by mobile devices and rarely interact with students who use mobile devices productively; and (3) the learner agrees the use of mobile devices in learning as it may benefit the students.

Research on the use of mobile learning applications called "duolingo" has been done as in [7] who found that: (1) there was an increase in language ability of $91.4 \%$; (2) there is an increase in the effectiveness measurement of 8.1 points per duolingo usage during one hour of research; (3) 
participants who have no prior knowledge of Spanish before, require an average of 34 hours for a semester, to understand Spanish-level universities; and (4) beginner participants recorded the highest increase, while nonbeginner participants recorded the lowest increase.

A similar study was conducted as in [8] in his study entitled "From Traditional Learning into Mobile Learning in Education at the University Level: Undergraduate Students' perspective" who found that: (1) mobile learning can mask deficiencies from traditional learning; (2) mobile learning is not a substitute for the traditional learning system, but rather as a complement; and (3) more than half of the participating students showed interest in using mobile learning.

While reference [9] in his research entitled "mobile learning and its impact on bussines English learning" found that using mobile learning in learning English can provide benefits: (1) interactive applications; (2) have diverse sources; (3) direct listening to English native speakers; (4) improve speech, speech, and listening; (5) flexibility, and freedom of learning; (6) can be studied anywhere; (7) improving students' self-confidence; and (8) feedback that can be done quickly.

The results of the above Teodorescu study are in line as in [10] his research entitled "the use of mobile learning management system and an academic achievement of online student" found that: (1) self-efficacy, innovation , ease of use of mobile learning is an internal factor and subjective norm which is an external factor that encourages students to use mobile learning management system; (2) facilitate students in learning that impact on learning outcomes; (3) full-time students often use mobile learning management systems, rather than students who work part-time.

Based on some research results as described above, it is hoped that the performance of Human Trainer Trainer Learning Media Trainer Auotonics S070 Trainer for Electric Motor Installation Learning can improve the learning process and learning outcomes of Vocational High School students. In relation to the above, this research aims to obtain the design, know the performance and determine the feasibility of Media Interface Trainer Human Mechanic Learning for Vocational Education in Indonesia.

This study was to obtain design, to know the performance and to determine the feasibility of Human Mechanic Trainer Learning Media Interface for Vocational Education in Indonesia.

\section{METHOD}

This research used research development (Research and Development). Research and Development, with object Trainer Human Mechanic Interface Auotonics S070 is done through the following stages: (1) analysis; (2) design; (3) implementation; (4) validation; (5) testing; and (6) testing in classroom learning.

The methods used in data collection include: (1) testing and performance monitoring of the Trainer Human Mechanic Interface Auotonics S070; (2) through questionnaires to find out students' responses of 30 students; And (3) the feasibility test and construct test for the Trainer Human Mechanic Interface Auotonics S070 is conducted by two media instructional experts.
Data analysis techniques that will be done in the first stage is to use descriptive qualitative that is exposing the product Designer after the design is implemented in the form of finished product and test the level of product feasibility. Then the second stage using descriptive quantitative, which describes the feasibility of the product to be implemented on the subjects of Electric Motor Installation in Vocational Secondary School Vocational Special 1 Surabaya. Qualitative data obtained then converted into quantitative data using Likert scale.

The Likert scale has gradefrom very positive to very negative that can be manifested in various words. The weighted value level used as the measurement scale is 4,3 , 2,1 .

After the percentage is obtained, the value is altered in the predicate statement which refers to the assertion that the quality and feasibility measure is categorized using the scale shown in Table 1 below.

TABLE 1. CATEGORY OF FEASIBILITY BASED ON RATING SCALE

\begin{tabular}{|c|c|c|}
\hline \multirow{2}{*}{ No } & \multicolumn{2}{|c|}{ Category of Feasibility Based on Rating Scale } \\
\cline { 2 - 3 } & Score in Percent (\%) & Feasibility Category \\
\hline 1. & $0 \%-25 \%$ & Very Inappropriate \\
\hline 2. & $>25 \%-50 \%$ & Less Eligible \\
\hline 3. & $>50 \%-75 \%$ & Decent Enough \\
\hline 4. & $>75 \%-100 \%$ & Very Decent \\
\hline
\end{tabular}

\section{RESULT AND DISCUSSION}

The assessment of the feasibility of Trainer Human Mechanic Interface Auotonics S070 is based on the quality aspect of content and objectives, quality of learning aspect, technical quality aspect and expediency aspect. Media assessment is done by construct validation test by media experts and (empirical test) usage test by learners.

\section{A. Content Validation Test Results by Media Experts}

The result of content validation test is questionnaire of expert media media. Questionnaire assessment of learning media experts is reviewed from six aspects namely aspects of characteristics, content, language, illustration, format, and manners. The percentage scoring scores are presented in Table 2 below.

TABLE 2. TEST RESULTS OF MEDIA VALIDITY (FROM SIX ASPECT)

\begin{tabular}{|c|l|c|c|c|}
\hline \multirow{2}{*}{ No } & \multicolumn{4}{|c|}{ Test Results of Media Validity (From Six Aspect) } \\
\cline { 2 - 5 } & $\begin{array}{c}\text { Aspect of } \\
\text { Assessment }\end{array}$ & $\begin{array}{c}\text { Average } \\
\text { Score }\end{array}$ & $\begin{array}{c}\sum_{\text {Students }} \\
\text { Percentage }\end{array}$ \\
\hline 1. & Characteristics & 24 & 25 & $96.00 \%$ \\
\hline 2. & Content & 20 & 25 & $80.00 \%$ \\
\hline 3. & Language & 13 & 15 & $86.60 \%$ \\
\hline 4. & Illustration & 18 & 20 & $90.00 \%$ \\
\hline 5. & Format & 17 & 20 & $85.00 \%$ \\
\hline 6. & Manners & 9 & 10 & $90.00 \%$ \\
\hline \multicolumn{5}{|c|}{ Average Percentage } \\
\hline
\end{tabular}


Based on the above exposure can be described in the form of bar charts as shown in Figure 1 below.

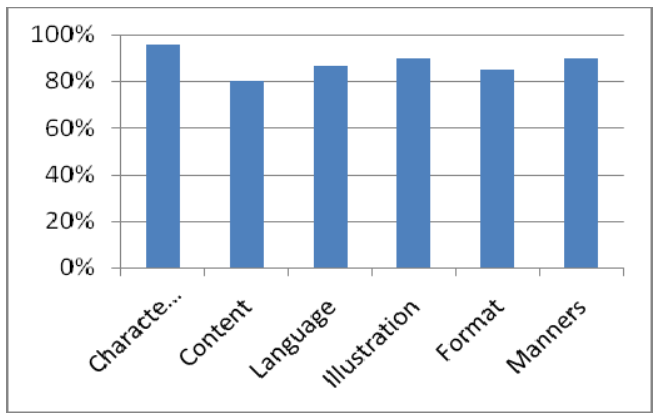

Fig. 1. Bar chart of test results from aspect content validity

Based on media characteristic aspect, Trainer get average score of $24(96.00 \%)$, content aspect get average score of $20(80.00 \%)$, language aspect get average score equal to $13(86.60 \%)$, aspect of illustration get average score equal to $18(90.00 \%)$, format aspect get average score equal to $17(85.00 \%)$, while from the aspect of manners get average score of $9(90.00 \%)$. Overall the validation level of learning media Trainer Human Mechanic Interface Auotonics S070 from the expert media assessment obtained an average percentage of $89.58 \%$, so it can be concluded learning media Trainer Human Mechanic Interface Auotonics S070 into the category "very eligible". In this evaluation, the media expert suggests some things that need to be improved quality the Trainer Human Mechanic Interface Auotonics S070.

\section{B. Construct Validity Test Results by Media Experts}

The result of construct validation test in the form of questionnaire of expert media appraisal. Questionnaire assessment of learning media experts is reviewed from two aspects, namely technical aspects and aspects of expediency. The percentage scoring scores are presented in Table 3 below.

TABLE 3. TEST RESULTS OF MEDIA VALIDITY (ASPECT OF TECHNICAL

\begin{tabular}{|c|c|c|c|c|}
\hline \multicolumn{5}{|c|}{ QUALITY AND UTILIZATION) } \\
\hline \multirow{2}{*}{ No } & \multicolumn{4}{|c|}{$\begin{array}{l}\text { Test Results of Media Validity (Aspect of } \\
\text { Technical Quality and Utilization) }\end{array}$} \\
\hline & $\begin{array}{l}\text { Aspect of } \\
\text { Assessment }\end{array}$ & $\begin{array}{l}\text { Average } \\
\text { Score }\end{array}$ & $\sum_{\text {Students }}$ & Percentage \\
\hline 1. & $\begin{array}{l}\text { Technical } \\
\text { Quality }\end{array}$ & 30 & 35 & $87.60 \%$ \\
\hline 2. & Utilization & 31 & 35 & $88.00 \%$ \\
\hline \multicolumn{4}{|c|}{ Average Percentage } & $87.80 \%$ \\
\hline
\end{tabular}

Based on the above exposure can be described in the form of bar charts as shown in Figure 2.

The data of expert media assessment evaluated from the aspect of technical quality get the average score of 30 $(87.60 \%)$, while from the aspect of expediency get average score equal to $31(88.00 \%)$. Overall validation level of learning media Trainer Human Mechanic Interface Auotonics S070 from the assessment of media experts, get average score of $87.80 \%$, so it can be concluded learning media Trainer Human Mechanic Interface Auotonics S070 into the category "very eligible".

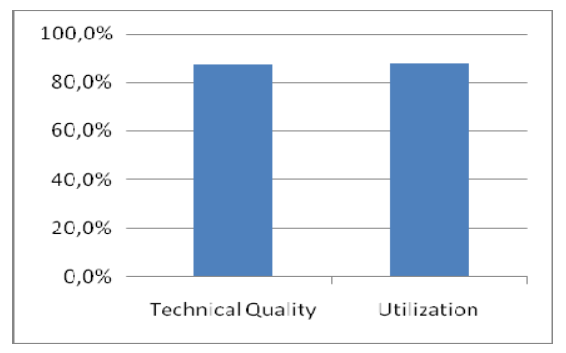

Fig. 2. Bar chart of test result from aspect construct validity

\section{Test Results Used by Learners}

Learning media Trainer Human Mechanic Interface Auotonics S070 was tested to students of Electrical Installation Engineering Department at Secondary School Vocational Special 1 Surabaya, which is a place to carry out the test usage to learners. Assessment is reviewed from four aspects namely the physical aspect and appearance. Percentage of assessment data for the learning media expert is presented in Table 4 below.

TABLE 4. PERCENTAGE OF USAGE TEST RESULTS
\begin{tabular}{|l|l|l|l|l|}
\hline \multirow{2}{*}{ No } & \multicolumn{4}{|c|}{ Percentage of Usage Test Results } \\
\cline { 2 - 5 } & $\begin{array}{c}\text { Aspect of } \\
\text { Assessment }\end{array}$ & $\begin{array}{c}\text { Average } \\
\text { Score }\end{array}$ & $\begin{array}{c}\sum_{\text {Students }} \\
\text { Percentage }\end{array}$ \\
\hline 1. & Performance & 3.67 & 30 & $84.00 \%$ \\
\hline 2. & Design & 3.48 & 30 & $82.08 \%$ \\
\hline \multicolumn{6}{|c|}{ Average Percentage } & $83.04 \%$ \\
\hline
\end{tabular}

Based on the above exposure can be described in the form of bar charts as shown in Figure 3 below.

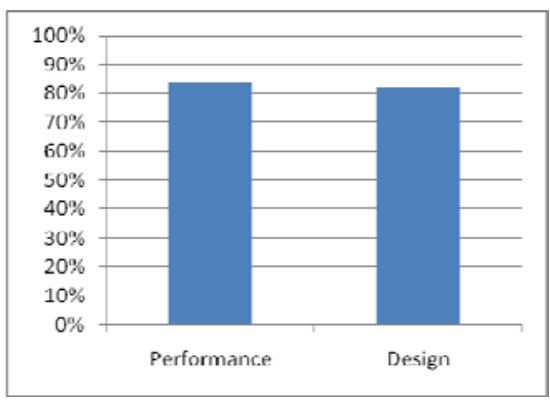

Fig. 3. Bar chart of Test Results Used by Learners

The data of the usage test by 30 students in the field evaluation phase of the Trainer Human Mechanic Interface Auotonics S070 viewed from the physical aspect gets average score of $3.67(84.00 \%)$, while the display aspect gets average score of $3.48(82.08 \%)$. Overall, the percentage of eligibility was $83.04 \%$. So it can be concluded the learning medium Trainer Human Mechanic Interface Auotonics S070 into the category of very eligible. 
Thus, the results of this study are: (1) the performance of Human Mechanic Interface Trainer is in line with the purpose of Vocational learning media in Indonesia; (2) overall, that the performance of Trainer Human Mechanic Interface, has been in accordance with the design; (3) various components of the Logic Panel Auotonics S070 as learning media, including the ledder circuit, has been in accordance with the needs of the subjects of Electrical Motor Installation; and (4) the media content test, by the instructional media experts, earns a "very reasonable category" with a percentage of $89.58 \%$.

Based on the results of research as described above, it is expected that the results of this learning media research will have benefits in the learning process is to facilitate the interaction between teachers and students, so that learning activities will be more effective and efficient. Kemp and Dayton [12] explain that the benefits of instructional media are: (1) the delivery of the subject matter can be uniformed; (2) the learning process becomes more clear and interesting; (3) the learning process becomes more interactive; (4) efficiency in time and effort; (5) improving the quality of student learning outcomes; (6) the medium allows the learning process can be done anywhere and anytime; (7) media can cultivate students' positive attitude toward learning materials and process; (8) change the role of the student in a more positive and productive direction; and (9) the media can make the abstract subject matter more concrete.

However, according to Mahnun [13], there are many studies of which learning media are most suitable for a particular purpose, and the results of the study show that: (1) not every teaching medium can be utilized to achieve any teaching objective; (2) all teaching media can assist teachers in implementing one or several functions in teaching, such as telling, controlling/checking, giving reinforcement and evaluating. There is even a possibility, the media took over the function of such a film that tells the process of cell growth. Furthermore, Winkel [14] said that media selection in addition to seeing their compatibility with specific instructional goals, subject matter, didactic procedures and student grouping forms, should also be considered about cost, availability of equipment, time needed, availability of electricity, technical quality, classrooms, and the ability of teachers to use the media appropriately.

\section{CONCLUSION}

The Trainer Human Mechanic Interface performance is in line with the objectives of the Vocational learning media in Indonesia. Overall, that the performance of the Trainer Human Mechanic Interface, has been in accordance with the design. Various components of Logic Panel Auotonics S070 as learning media, including ledder circuit, has been in accordance with the needs of subjects Electric Motor Installation. Test of media content, by expert of learning media, obtained "very decent category" with percentage equal to $89.58 \%$. Test of media content, by expert of learning media, obtained "very decent category" with percentage equal to $89.58 \%$. Media trials in learning of 30 students in SMK Special Navy 1 Surabaya, obtained "very decent category" with percentage equal to $83.04 \%$.

\section{ACKNOWLEDGMENT}

This research can be done with the help of various parties. For that in this occasion conveyed thanks to Head SMK Special AL-1 Surabaya which has given an opportunity where this research can be done smoothly in accordance with the planned time. To the students who have been actively involved in this research, so that the necessary data can be obtained completely, also delivered many thanks.

\section{REFERENCES}

[1] Slameto, "Belajar dan Faktor-faktor yang Mempengaruhinya," PT Rineka Cipta, Jakarta, 2010.

[2] J. Dabutar, "Pengaruh Media Pembelajaran Terhadap Hasil Belajar Pengelasan pada Siswa yang Berprestasi Tinggi dan Rendah di SMK Swasta 1 Trisakti Laguboti- Kabupaten Toba Samosir," Digital Library Universitas Negeri Malang, 2007.

[3] Preeti, "Education and role of media in education system," in International Journal of Scientific Engineering and Research, vol. 2, Issue 3, March 2014, 174-177.

[4] O.D. Omadara, E.I Adu, "Relevance of educational media and multimedia technology for effective service delivery in teaching and learning processes," in IQSR Journal of Research \& Method in Education, Volume 4, Issue 2 Ver.1 (Mar-Apr.2014), 48-51.

[5] A. N. Akhtar, R. A. Ali, "Use of media for effective its importance: Some consideration," in Journal of Elementary Education, 18 (1-2), 35-40.

[6] P. Pollara, "Mobile learning in higher education: A glimpse and a comparison of student and faculty readiness, attitudes, and perceptions," 2011, unpublished.

[7] R. Vesselinoy, J. Grego, "Duolingo effectiveness study," New York, 2012.

[8] M. Sarrab, A. Alzahrani, N.A. Alwan, O. Alfarraj, "From traditional learning into mobile learning in education at university level: Undergraduate students perspective," in International Journal of Mobile learning and organization, 8 (3-4), 167-186, 2014.

[9] A. Teodorescu, "Mobile learning and its impact on buissines English learning," in Procedia-Social and Behavioral Sciences 180, 1535$1540,2015$.

[10] I. Han, W. S. Shin's, "The use of mobile learning management system and an academic achievement of online student," in Computers \& Education, 2016.

[11] Sugiyono, "Metode Penelitian Pendidikan (Pendekatan Kuantitatif, Kualitatif dan R\&D)," CV. Alfabeta, Bandung, 2011.

[12] I. Falahudin. (2014). Jurnal Lingkar Widyaiswara (Www.juliwi. com), Edisi 1 No. 4, Oktober - Desember 2014, p.104-117. ISSN: 2355-4118.

[13] N. Mahnun. (2012). Media Pembelajaran (Kajian terhadap Langkahlangkah Pemilihan Media dan Implementasinya dalam Pembelajaran): Jurnal Pemikiran Islam, Vol. 37, No. 1, Januari-Juni 2012.

[14] W.S. Winkel. (2005). Psikologi Pengajaran, Media Abadi, Yogyakarta. 